Hungarian Educational Research

Journal

\section{Higher Education Internationalization: Insights from Kazakhstan}

Zakir Jumakulov ${ }^{14}$ \& Adil Ashirbekov ${ }^{15}$
2016, Vol. 6(1) 37-59

(C) The Author(s) 2016

http://herj.lib.unideb.hu

Debrecen University Press

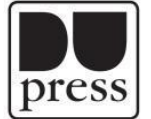

DOI: 10.14413/HERJ.2016.01.03

\begin{abstract}
This paper sheds light on the approaches, forms, goals and influencing factors of internationalization of higher education in Kazakhstan. Kazakhstan's education system is regulated centrally by the Ministry of Education and Science, and most internationalization initiatives are set by the Ministry. The Ministry sees the role of internationalization of higher education in advancing Kazakhstan's education system, increasing the attractiveness of higher education, and developing a multicultural society. The government promotes higher education internationalization by: sponsoring degree and non-degree student and faculty mobility programs; signing intergovernmental agreements on educational exchange; incentivizing the internationalization of curriculum by setting accreditation regulations; creating an international university; and signing the Bologna Process which requires universities to make deeper structural reforms. These governmental initiatives were the main drivers for Kazakhstani universities to internationalize. Although most universities adopted strategies on internationalization, their approaches could be characterized as an activity approach rather than a comprehensive approach to internationalization.
\end{abstract}

Keywords: higher education, international education, educational quality, universities, student mobility, faculty mobility, Kazakhstan

\footnotetext{
14 Zakir Jumakulov, Nazarbayev University Graduate School of Education, Astana (Kazakhstan), zakir.jumakulov@nu.edu.kz

15 Adil Ashirbekov, Nazarbayev University Graduate School of Education, Astana (Kazakhstan) aashirbekov@nu.edu.kz
} 
HERJ Hungarian Educational Research Journal Vol 6 (2016), No 1 


\section{Introduction}

This paper sheds light on the goals of, approaches to, and forces influencing internationalization of higher education in Kazakhstan. Kazakhstan is one of the former republics of the Soviet Union, with a geographic size of Western Europe and population of only 18 million. It is a landlocked country bordering Russia, China, Kyrgyzstan, Uzbekistan, and Turkmenistan. After reaching the goal of being among the top 50 countries with the most competitive economies, Kazakhstan set a new goal to reach the top 30, which requires the development of its higher education system (Strategy Kazakhstan 2050, 2012).

The Kazakhstani government is actively reforming its higher education system by borrowing practices of more developed countries. This is similar to other Central Asian countries who implemented 'post-socialist education reform package' - extension of schooling to twelve years, reduction of the number of subjects in the curriculum, introduction of new subjects, student-centered learning, standardized student assessment, reorganization of schools by either closing them down or merging them with ones that were larger and better equipped, decentralization of educational finance and governance, liberalized regulations for textbook publishing, and private-sector involvement in higher education (Silova \& Steiner-Khamsi, 2008).

Particularly, initiatives such as government-sponsored academic mobility programs, intergovernmental agreements on educational exchange, encouragement for international accreditation of universities, participation in the Bologna Process, and the establishment of a university according to international standards influenced the internationalization of higher education in Kazakhstan. These separate initiatives could be considered activities of internationalization. An activity approach to higher education internationalization defines internationalization in terms of categories or types of activities. De Wit (2011) argues that an activity approach is the most common strategy .

An activity approach to internationalization is usually contrasted with the process approach, which is defined by Knight (2008) as "the process of integrating an international, intercultural or global dimension into the purpose, functions or delivery of post-secondary education" (p. 21). The process approach is closely related to what Hudzik (2011) defines as comprehensive internationalization:

a commitment, confirmed through action, to infuse international and comparative perspectives throughout the teaching, research, and service missions of higher education. It shapes institutional ethos and values and touches the entire higher 
education enterprise. It is essential that it be embraced by institutional leadership, governance, faculty, students, and all academic service and support units. It is an institutional imperative, not just a desirable possibility (p. 6).

Kazakhstan does not have a specific national strategy for internationalization as do countries as the UK, and policy documents do not provide a consistent definition of internationalization. Thus, governmental and institutional initiatives are not always connected with each other. The internationalization of higher education in Kazakhstan has a fragmented and diverse outlook, although each internationalization initiative has the ultimate aim to develop Kazakhstan's higher education system. However there is the Strategy for Academic Mobility in the Republic of Kazakhstan for 2012-2020, which highlights the importance of accounting for global processes and trends to develop the higher education system, stating: "It is becoming clear nowadays that national systems of higher education cannot be developed outside of global processes and trends, and without considering the demands of the global labor market" (Ministry of Education and Science of the Republic of Kazakhstan, 2012: 5).

The aim of internationalization, as described by a Kazakhstani policymaker, is "improving the efficiency of the educational and research activities, the expansion of the mobility of faculty and students, [and] compliance with international standards of quality educational services" (Omirbayev, 2016, Slide 5). This suggests that increasing the quality of education is an important goal of internationalization in Kazakhstan and it puts emphasis on academic mobility. The connection between internationalization and education quality is also emphasized in a definition of internationalization recently proposed by de Wit (2015):

The intentional process of integrating an international, intercultural or global dimension into the purpose, functions and delivery of post-secondary education, in order to enhance the quality of education and research for all students and staff, and to make a meaningful contribution to society (Slide 24).

In this paper, we studied available policy documents and prior research and conducted Internet searches to identify relevant government initiatives and forces that may drive internationalization in Kazakhstan's higher education system.

\section{Kazakhstani Context}

As with other Soviet states, Kazakhstan's higher education was centrally planned; the government provided educational programs and curriculum standards. Universities were part of a supply chain in the planned economy, producing graduates who would then be distributed to workplaces. Education was free for the users and research was conducted 
separately in research institutes. The Soviet legacy can still be found in the separation of teaching and research, the government-regulated salary system for faculty, and centralized curriculum, administration and governance (Jones, 2011). These characteristics of Kazakhstan's higher education system are not in sync with the current trend of internationalization or Bologna principles (Tomusk, 2011).

After independence from the Soviet Union in 1991, a series of reforms took place in Kazakhstan's education system as well as in almost all fields of it's economy. As other post Soviet states, Kazakhstan's higher education started to 'convert from the Soviet model that was secured from the influence of outer world for decades into a new academic system that is fully integrated into the global academic network' (Kuraev, 2014). The new law on education allowed for the establishment of private universities; more autonomy was granted to higher education institutions in academic matters; three levels of higher education (Bachelor's, Master's and PhD) were introduced; and credit systems (first the US credit system and later the European Credit Transfer System) were implemented. In the aftermath of legislative changes, the number of universities increased from 55 in 1991 to 181 in 2005 (Nazarbayev University Graduate School of Education, 2014), in response to market demand. However, the quality was inconsistent, with some institutions offering low quality education. In response to concerns about quality, the Ministry of Education and Science steadily reduced the number of universities to its 2014 level $(n=126)$ through accreditation requirements (Ministry of National Economy of the Republic of Kazakhstan, 2015a).

Accreditation requirements had a significant influence on private institutions, as it was mainly the private institutions that were eliminated. The decrease in the number of higher education institutions was followed by a decline in higher education enrollment. The number of enrolled students was 419,000 in 1996; enrollment peaked in 2005 at 775,104, but was gradually reduced to the current level of 477,387 (Ministry of National Economy of the Republic of Kazakhstan, 2015b). Low birth rate in the 1990's is believed to be another reason for the recent decrease in higher education enrollment (Ministry of National Economy of the Republic of Kazakhstan, 2015c).

\section{Activities of Internationalization}

The Kazakhstani government articulates the importance of the internationalization of higher education through various policy documents, such as the Strategy for Academic Mobility in the Republic of Kazakhstan for 2012-2020 and the State Program on Educational Developments, both of which have set specific goals for internationalization (Ministry of Education and Science of the Republic of Kazakhstan, 2012). The Ministry initiated several programs and structural reforms that have also influenced internationalization of higher education of Kazakhstan. They include: sponsoring study 
abroad through the Bolashak international scholarship program; a university-based student mobility program; a faculty exchange program; the establishment of Nazarbayev University; and new programs at eleven Kazakhstani universities in collaboration with international university partners to prepare specialists for the demands of the State Program on Industrial Development (Ministry of Education and Science of the Republic of Kazakhstan, 2014). In the following sections, we discuss the influence of these initiatives on the internationalization of Kazakhstan's higher education.

\section{Outbound Student Mobility}

International student mobility is endorsed on the national level in Kazakhstan, and indicators of international mobility are stated in policy documents outlining educational development strategies. There are several schemes that enable students from Kazakhstan to fund their study abroad, which are summarized below:

Kazakhstani government funded programs

- $\quad$ Bolashak Program (degree programs and internships)

- Academic mobility program (non-degree programs)

Intergovernmental grant exchange

- Eight intergovernmental agreements with equivalent levels of academic exchange: Egypt (7), Belarus (6), Romania (5), Ukraine (40), Kyrgyzstan (5), China (100), Slovakia (4), Mongolia (5)

Grants from other governments and international organizations

- $\quad$ Russian Federation (300 grants in 2016)

- European Union (Erasmus plus), USA (Fulbright), Germany (DAAD ), India (ITEC), etc.

University level student exchange

- $\quad$ University of Shanghai Cooperation Organization (USCO)

- $\quad$ Network of Commonwealth of Independent States (CIS).

- Inter-university agreements

Kazakhstan is among 15 countries of the world with the largest number of students studying abroad, and the first in the Central Asian region. (University World News, 2014). Although the Kazakh government provides a considerable amount of funding for study abroad programs, it only covers about 10 percent of it, whereas the vast majority of the 
outbound students study at for their own family's cost. Having comparatively higher income in the region and limited higher education in the country can be considered as main pulling factors contributing to this number (Agarwal and Winkler, 1985). Kazakhstan is the only country in the region with a higher middle income level. Also, higher education in Kazakhstan is limited to those who scored 50 points out of a maximum of 125 in Unified National Test (UNT). For example, in 2015, out of 125000 school leavers, 87000 participated in UNT and 20000 were not able to attain a passing score, some of whom could have looked at opportunities to study abroad. Among self funded students studying abroad, Russia is the main destination that hosts about 35000 students. (UNESCO, n.d.).

Table 1 - Number of students abroad/Number of international students hosted in Central Asian countries in 2014

\begin{tabular}{lccc}
\hline$\#$ & Country & Number of students abroad & Number of international students hosted \\
\hline $\mathbf{1}$ & Kazakhstan & 48875 & 19336 \\
$\mathbf{2}$ & Turkmenistan & 35854 & 1158 \\
$\mathbf{3}$ & Uzbekistan & 18783 & 378 \\
$\mathbf{4}$ & Tajikistan & 9749 & 87 \\
$\mathbf{5}$ & Kyrgyzstan & 5885 & 11263 \\
\hline
\end{tabular}

Source: UNESCO Institute for Statistics, 2014

Other than government and private funding, students can fund their academic mobility through intergovernmental student exchange agreements, which gave opportunity to 505 Kazakhstani students in 2015 to study in 13 countries (Omirbayev, 2016). The largest student exchange agreement is signed with China ( $n=100$ students).

Other opportunities are also available through inter-university agreements, international programs, financed by other countries, political associations and international organizations. These include the Fulbright Scholarship Program, the Global UGRAD, Chevening, Erasmus plus, and DAAD programs, the University of Shanghai Cooperation Organization (USCO) and the Network of Commonwealth of Independent States (CIS) Universities. International scholarship programs such as the ones listed above not only allow students from Kazakhstan to have international experience, but also often promote cooperation between Kazakhstani universities and international partners (Ashirbekov, Jumakulov, \& Lisnyak, 2013). For example, USCO University is a network of universities, including 14 Kazakhstani universities, aimed at promoting student and faculty mobility, facilitating research and academic partnerships, and creating mechanisms for the mutual recognition of postsecondary credentials (University of Shanghai Cooperation Organization, n.d.). The Network of CIS Universities aspires to promote student exchange at the graduate level through facilitating the creation of joint degree programs (Network of CIS Universities, 2015). Between 2007 and 2013, 23 universities in Kazakhstan participated in a total of 22 Erasmus Mundus projects partially funded by the European Union (Ashirbekov et al., 
2013). Participation in the Erasmus Mundus program is also aimed at fostering cooperation among universities from different nations.

\section{Bolashak International Scholarship Program}

The government-funded Bolashak international scholarship program and a universitybased non-degree mobility program are the two largest state programs, which we discuss in more detail below.

Initiated in 1993, the Bolashak international scholarship program was aimed at preparing specialists for the political and economic transition that Kazakhstan was embarking on. Since its inception, more than 11,000 students have been trained through this mobility program (Center for International Programs, 2015).

In the typology of 183 international scholarship programs, the Bolashak program is categorized as a program aiming at developing advanced knowledge in developed nations. Among 94 programs in this category are Becas (Chile), Kristjan Jaak (Estonia) and others. This category is contrasted with programs that aim at training students to develop basic skills in developing countries, developing advanced knowledge in developing nations and providing opportunities for short term studies (Perna et al., 2014).

The Bolashak program is ongoing, although its nature has changed. Changes in program characteristics are related to the government's efforts to align personal choice, industrial needs, and the country's strategic development (Sagintayeva \& Jumakulov, 2015). Until 2011, the Bolashak program was aimed at preparing specialists for the general labor market. Since then, the program is focused on training specialists in national priority areas at selected universities' postgraduate programs. In addition to promoting the degree attainment at the graduate level abroad, the Bolashak program also awards internships for university staff, faculty, and civil servants.

The program awards full scholarship that covers tuition and fees, a monthly stipend, transportation, medical insurance and book allowances. In 2014, the Kazakhstani government allocated 16.5 billion Tenge (about 105 million US dollars) to the program (Official Site of the Prime Minister of the Republic of Kazakhstan, 2014). Eligible categories of applicants for 2016 are: people working in public service, arts, and mass media; faculty members or researchers; engineers; those who were self-admitted to a Master's or PhD program abroad; and those who were admitted to the top ten MBA schools in the world. All applicants for the graduate degree programs should have at least 
two years of work experience in their respective field. The selection process consists of proficiency in Kazakh and a foreign language and an assessment of psychological wellbeing (Perna et al., 2015).

All applicants to the Bolashak program must demonstrate collateral or have guarantors who are willing to assume financial responsibility if the scholarship recipient fails to meet the contractual obligations associated with receipt of the scholarship (Perna et al., 2015). Although it might seem controversial, the policy has proven to be effective, as the nonreturn rate is under one percent. One of the main conditions for scholarship recipients is the obligation to work in their specialty area in Kazakhstan for five years after program completion.

Contribution of the Bolashak program to the country's development is continuously noted by policymakers; there are already well-known graduates in government, business, medicine, and other industries. Research on this program suggests that Bolashak scholarship recipients may acquire global competencies abroad; Kazakhstani employers reportedly value the strong soft skills and foreign language proficiency of Bolashak program graduates (Perna, Orosz, \& Jumakulov, 2015).

\section{Short-term Study Abroad}

While the Bolashak program supports study abroad that leads to degree attainment, more recent governmental initiatives support short-term study abroad opportunities. The program was created to reach the Bologna goal of having at least $20 \%$ of each Bolognasignatory nation's postsecondary students participate in an international study experience by 2020 (Communiqué of the Conference of European Ministers Responsible for Higher Education, 2009). Almost 7,000 Kazakhstani students received this governmental scholarship for short-term study abroad since funding for this type of mobility became available in 2011 (Diagram 1) (IAC, 2015). 


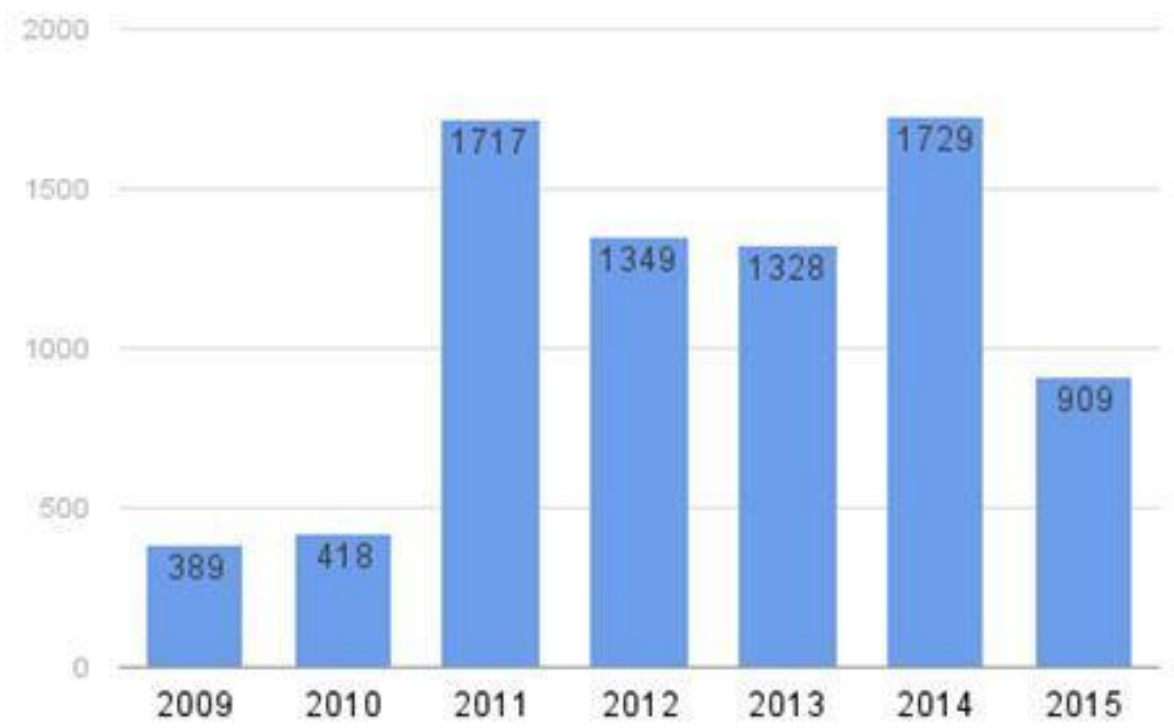

Diagram 1 - Number of Kazakhstani students funded by short-term study abroad program in 2009-2015

Unlike the Bolashak program which is administered by the Center for International Programs, grants for short-term study abroad are administered at the university level and recipients may only study at host institutions with which the home university has signed contractual agreements. Grants are not limited by field of study (Concept of academic mobility of students studying in universities of the Republic of Kazakhstan, 2011). The Ministry of Education and Science of the Republic of Kazakhstan funds the short-term mobility program and determines the number of scholarships to award to each university. From 2012 till 2015, the government allocated 2.36 billion Tenge (about 12.8 million US dollars) to the program (Omirbayev, 2016).

Grants for short-term study abroad cover travel, living, and insurance costs. Host universities agree to waive tuition costs and provide free accommodations for participating students (Concept of academic mobility of students studying in universities of the Republic of Kazakhstan, 2011).

A survey of participating universities found that there are a number of challenges pertaining to the implementation of the program. The credit transfer system and discrepancy in academic periods are part of the problem. Also Kazakhstani universities find it difficult to find partners from such countries as the USA and the UK, where tuition fees are typically higher than in most European countries. Substantial differences in tuition, fees, and living costs between Kazakhstan and more developed countries and language barriers have restricted the choice of destinations for participating institutions and students and led to the cluster of students in countries that used to be under Soviet influence. However, to fully comply with the Bologna Process mobility requirements, the 
Kazakhstani government encourages universities to send students to partner institutions within the European Higher Education Area, which is reflected in the distribution of the students, in 2015 Europe hosted 840 students, USA 50 students and South Asia hosted 19 students (IAC, 2015).

Although the international experience of Kazakhstani students is considered to have a positive effect in individual and system level, at university level this is considered one of the biggest challenges for some local universities. The number of students studying abroad constitute about 10 percent of the students studying in Kazakhstani HEIs. This is especially sensitive now, when the number of the student-age population is falling in the country and especially sensitive for the universities in the northern regions of the country bordering with Russia. They have to compete with Russian universities and some Kazakhstani universities are not successful in this, for example, over the past three years, the North Kazakhstan State University lost one third of their student body from about 7100 to 4800 students (IAC, 2015: 171). Reflecting to this the Ministry is considering to increase the access to higher education in Kazakhstan.

\section{Inbound Student Mobility}

Although the Strategy for Academic Mobility in the Republic of Kazakhstan for 2012-2020 states the importance of balanced mobility, currently only 9,077 international students study in Kazakhstan (Ministry of National Economy of the Republic of Kazakhstan, 2015d), whereas about 48,875 Kazakhstani students are studying abroad (UNESCO, n.d.). Most international students studying in Kazakhstan come from one of the Commonwealth of Independent States (CIS) nations, India, Pakistan, China, and Afghanistan (UNESCO, n.d.).

During the period of 2000-2015 the average number of international students in Kazakhstan was 11000 students, which is about 2.4 percent of the total number of Kazakhstani tertiary students in 2015/16. The Ministry of Education has the goal of increasing this number to 5 percent by 2019 (SPESD, 2016).

When Kazakhstan was part of the Soviet Union, internationalization referred mainly to cross-border partnerships with countries under Soviet influence. Such partnerships, including institutional partnerships and student mobility, extended not only across the Soviet Union and the Eastern bloc but also to countries such as India, Pakistan and Cuba. Some of these international partnerships are still functioning today, as evidenced by the relatively large number of students from India $(n=1,003)$ and Pakistan $(n=489)$ studying in Kazakhstani universities in 2004 (Ministry of National Economy of the Republic of 
Kazakhstan, 2015d). In more recent years, the number of students from these countries has decreased. Currently, Indian students account for $8 \%$ and Pakistani students account for $4 \%$ of all international students in Kazakhstan; students from these nations typically enroll in medical schools (Ministry of National Economy of the Republic of Kazakhstan, 2015d).

The majority of international students (approximately 70\%) come from CIS countries (Ministry of National Economy of the Republic of Kazakhstan, 2015d). While data on student profiles from CIS countries is not available, it is likely that most international students coming to Kazakhstan from these countries are ethnic Kazakh students, also called "Oralmans" (translated as returnees from Kazakh). Annually 2 percent of government scholarship is allocated for them. Seven (7\%) percent of all international students in Kazakhstan are from China, many of whom may also be ethnic Kazakhs. Anecdotal evidence suggests that as the level of business activity is increasing between Kazakhstan and China, Chinese citizens of non-Kazakh ethnicity also increasingly choose to study in Kazakhstan and then continue their career in Chinese companies operating in Kazakhstan. These Chinese students typically pay fees at Kazakhstani universities, as government grants are only available to international students who study at Kazakhstani universities as part of a bilateral exchange agreement.

Students from Afghanistan make up four percent of all international students in Kazakhstan (Ministry of National Economy of the Republic of Kazakhstan, 2015d). Afghan students study in Kazakhstan as part of the Official Development Assistance (ODA) program through which the Kazakhstani government aids Afghanistan. The ODA program allocates 1,000 grants for five years to Afghan students; the program is meant to contribute to the economic development of Afghanistan and mitigate security risk in the region as international coalition troops withdraw from the country (Orazgaliyeva, 2014).

To further increase the number of incoming students, universities are increasing the English language courses and programs. This is also due to the broader trilingual policy at all levels of education. The literature suggests that inbound mobility can have positive benefits, such as creating an international environment in the classroom among others. However, in her study, B. Leask concludes that it does not occur by default and that the involvement and support of faculty and the entire university community is needed. More work is needed to promote their involvement in this process.

\section{International Faculty Exchange}

Faculty play an important role in the internationalization of higher education. Stohl (2007) argues that "the chief challenge for developing and sustaining internationalization in the context of the challenges and opportunities of the $21_{\text {st }}$ century is the engagement of 
the faculty" (p. 359). Exposing the faculty to international experiences may contribute to professional development, increase cultural awareness, and result in the adoption of novel teaching methodologies and choice of curricular content (Biraimah \& Jotia, 2013). Eurasian National University, one of the leading national universities in Kazakhstan, describes its commitment to attracting international faculty in order to improve the quality of educational programs, expand the faculty network, develop joint research projects with scientists from other nations, increase the number of publications in international journals, improve the quality of scientific publications, improve the quality of doctoral and master's degree programs, promote joint ventures with partner universities from other nations in the form of double-degree master's and doctoral programs, and form a basis for further scientific and educational cooperation (Eurasian National University, n.d.).

The Kazakhstani government promotes the recruitment of international faculty and the sending of Kazakhstani faculty abroad through Bolashak program and individual award for selected faculty members. The Bolashak program sponsors faculty members and research staff to earn a doctoral degree abroad or undertake a research internship abroad. Faculty and research staff whose foreign language proficiency is insufficient to facilitate independent research or doctoral studies abroad may receive funding for foreign language training if selected for Bolashak participation. Upon completion, program participants are contractually obligated to work for their Kazakhstani university for at least three years in the case of a research internship grant and for five years in the case of a degree abroad scholarship (Government of the Republic of Kazakhstan, 2015).

Another opportunity for Kazakhstani faculty to obtain international experience is through receipt of a state award for outstanding faculty member. According to the governmental decree that established the program, the title of outstanding faculty member is awarded to 200 faculty members (Government of the Republic of Kazakhstan, 2012). Universities nominate candidates from among their faculty members; each university is allowed to nominate one candidate per every 50 faculty employed at the university. The list of candidates is then considered by a commission consisting of representatives of the Ministry of Education and Science, other government representatives, leading scientists and specialists, and representatives from political parties and non-governmental organizations. Recipients can use the awards for conducting research or training at universities or laboratories abroad (Government of the Republic of Kazakhstan, 2012).

In addition to promoting the international experiences of Kazakhstani faculty, the Kazakhstani government also allocates funds for universities to attract an annual 300 international faculty members and researchers to Kazakhstani universities through the Attracting International Researchers program (Omirbayev, 2016). The program requires 
that the visit of international faculty should be at least 12 days. Governmental funding is disbursed annually, and usually not until several months after the start of the academic year, which means Kazakhstani universities have limited time for contracting and other logistics (Workshop on Mechanisms of Internationalization of Higher Education, 2016). Kazakhstani universities also face difficulties in establishing connection with universities abroad and attracting faculty members for visits due to limited language competency among Kazakhstani university staff and faculty (Sagintayeva \& Ashirbekov, 2014). The British Council estimated that in 2011, only four percent of university faculty based in Almaty had a fully operational command of English (Woodword, 2011). Despite these challenges, 7,679 international faculty members and researchers from Europe, the US, East Asia and Russia have visited Kazakhstani universities since 2009 (Omirbayev, 2016).

Another opportunity to involve international faculty in Kazakhstani higher education is through PhD supervision. It is required for all PhD students in Kazakhstan to have one internal and one international supervisor (State Educational Standard of Republic of Kazakhstan, 2011). This requirement is to ensure the quality of PhD training; the expectation is that the international supervisor will help Kazakhstani doctoral students prepare at least one paper acceptable for publication in an international research journal that has non-zero impact-factor or is included in the Scopus database (State Educational Standard of Republic of Kazakhstan, 2011).

\section{Establishment of an International University}

An important element of Kazakhstani higher education reform was to create a flagship university. In the pre-2010 legal environment, it was not possible to have an autonomous university. In 2010, a special law for Nazarbayev University was adopted, which allowed the creation of a university outside system regulations (Law on Status of Nazarbayev University Nazarbayev Intellectual Schools and Nazarbayev Fund, 2011). The new university was given academic and administrative autonomy and substantial financial resources. Located in the capital city of Astana, Nazarbayev University (named after Nursultan Nazarbayev, Kazakhstan's President since the nation's 1991 independence) is a Western-style, English language university (Hartley et al., 2015).

Nazarbayev University has a unique partnership structure, with each school of the university created in partnership with distinguished universities around the world. For example, the NU Graduate School of Education was created through partnerships with the Faculty of Education of the University of Cambridge and the Graduate School of Education of the University of Pennsylvania. Other partner universities include Duke University, Singapore National University, and the University of Wisconsin Madison (Hartley et al., 2015). 
Generous governmental funding allowed NU to recruit faculty and administration internationally. These faculty members have brought diverse international perspectives into the teaching and learning functions of the university. As stated in the mission statement of $\mathrm{NU}$, the university is expected "to be a model for higher education reform and modern research in Kazakhstan and to contribute to the establishment of Astana as an international innovation and knowledge hub" (Nazarbayev University, 2013: 7). The state program on education and science development action plan states that all universities should be implementing the experience of the NU in terms of academic and administrative autonomy, which has international dimensions in it (SPESD, 2016).

\section{International Graduate Programs at Kazakhstani Universities}

The latest national initiative that influences the internationalization of at least some Kazakhstani universities is the training of specialists for the implementation of the State Program on Industrial Development of Kazakhstan 2015-2019 (SPID, 2014). Kazakhstan's economy is a resource-based economy heavily dependent on oil. To diversify its economic portfolio, the government identified six priority industries (metallurgy, chemical industry, petrochemical industry, machinery, construction materials, and food industry) to be developed though the SPID program.

After the first five years of the State Program of Forced Industrial-Innovative Development 2010-2014, it was determined that one of the major challenges in implementing the program was the lack of appropriately trained personnel (SPFIID, 2010; SPID, 2014). To address this problem, the Ministry of Education and Science selected eleven Kazakhstani universities to create new graduate-level programs in partnership with universities abroad and with companies participating in SPID (Omirbayev, 2016). Partnering international universities are expected to ensure that new programs comply with the same quality requirements as at their own institutions. These new programs are expected to have a multiplicative effect on other programs of participating universities and beyond. In the 2015-2016 academic year, 24 master's degree programs and the same number of laboratories were upgraded in the eleven selected universities to train an estimated 1,900 students (Ministry of Education and Science of the Republic of Kazakhstan, 2014).

As part of the SPIID program, the Kazakhstani government also provides funds for training university leadership and faculty, signing contracts with universities abroad and procuring necessary equipment for laboratories (Nazarbayev University Graduate School of Education, 2015). The training for university leadership and faculty includes three model courses, one of which involves visiting universities in the US, UK, Japan and Singapore. In these training sessions, university leaders and faculty are divided into three 
groups to learn the best practices of the institutions abroad in entrepreneurship, research and leadership (Nazarbayev University Graduate School of Education, 2015).

\section{International Accreditation}

Following the recommendation by the 2007 OECD Review (Organisation for Economic Cooperation and Development, 2007), Kazakhstan established a system of accreditation for universities by independent agencies. Currently, eight international and two national accreditation agencies oversee the quality of Kazakhstani universities. Accreditation is voluntary, but there are advantages to obtaining it. Accredited universities do not need to go through the government attestation process. More importantly, from 2015, only those universities who have at least one program accredited are eligible for the government tuition grants (Law on Education, 2015). To date, international accrediting agencies have accredited a total of 252 programs in 30 Kazakhstani universities, while national agencies have accredited 390 programs in 66 universities (Omirbayev, 2016).

Although it is not clear how international accreditation influences the internationalization of higher education, it was perceived as the most important internationalization priority in a survey conducted by international office representatives employed at Kazakhstani universities (Sparks et al., 2015). One third of respondents ranked accreditation as the first priority in internationalization efforts (Sparks et al., 2015). The Ministry will be further incentivising universities to go through international accreditation, for example new provisions in Law on Education, it states that those universities who obtained international accreditation will be allowed to issue their own diploma.

\section{Regional Forces that Influence the Internationalization of Higher Education}

The Kazakhstani government's attempts to advance the nation's higher education system were mediating regional and global forces that influence the internationalization of higher education. Kazakhstan's aspiration to become part of the European Higher Education Area (EHEA) led to the signing of the Bologna Process. The Bologna Process is the main regional force pushing the internationalization of higher education in Kazakhstan. Several Kazakhstani universities signed the Magna Charta Universitatum in 2003; other Kazakhstani universities also became signatories in later years. In 2010, the Kazakhstani government signed the Bologna Declaration and became a member of the Bologna Process with the goal of harmonizing the nation's higher education system with that of Europe. The commitment to higher education reform in line with Bologna principles is reflected in the State Program of Education Development for 2011-2020, which stipulates the "integration into the European Higher Education Area through bringing the content and structure of higher education into compliance with the Bologna Process" (Ministry of Education and Science of the Republic of Kazakhstan, 2010: 46). 
As part of the State Program of Education Development, the Center for Bologna Process and Academic Mobility (CBPAM) was created in 2012 with the mission of "promoting proper and full implementation of the agreed principles of the Bologna Process in the Republic of Kazakhstan at the national and university levels in order to ensure the competitiveness of the higher education system" (CBPAM, 2012: 5). The center is subordinated to the Ministry of Education and Science. It provides guidelines for universities on the implementation of Bologna compliance reforms and activities, monitors and analyzes their implementation, and interacts with the ministry and the Bologna Process Follow-Up Group. Most universities have a person or unit responsible for overseeing the implementation of the Bologna Process and reporting to the CBPAM (Sparks et al., 2015). At least some institutional stakeholders perceive the Bologna principles as having a guiding role in internationalization, as evidenced by a statement from a university representative who likened the Bologna process to a lighthouse (Sparks et al., 2015).

Pursuant to implementing the principles that define the Bologna Process and the EHEA, the government identified the following areas for future reforms in Kazakhstan's higher education system: developing and implementing a Kazakhstani National Qualification Framework (NQF); developing a NQF for lifelong learning; creating a national higher education quality assurance system; developing degree programs that are compatible with Bologna Process provisions; creating up-to-date mechanisms for the recognition of prior learning; enhancing the portability of student grants and loans; increasing student and academic staff mobility (e.g., with attention to visa, residence, and work permit procedures); increasing university autonomy; and increasing the level of students' participation in the modernization process (Dixon \& Soltys, 2013).

The Kazakhstani government has already implemented the NQF, introduced the threecycle degree system, adopted the European Credit Transfer System (ECTS), and created a quality assurance policy in higher education. "Diploma supplements," or brief summaries of the curricular content and skills associated with degree programs, are issued in Kazakh, Russian, and English languages to all university graduates. These governmental initiatives served as a good basis for other internationalization activities, such as academic mobility and joint degree programs. In 2015, there were 338 joint undergraduate programs between Kazakhstani and international universities, 185 master's degree programs and $37 \mathrm{PhD}$ programs (Omirbayev, 2016).

Joining the EHEA and signing the Bologna Process is a major regional force that triggered other internationalization activities on national and institutional levels in Kazakhstan. The same could not be said about regional university networks in which Kazakhstani universities are involved. For example, the Network of CIS Universities can be seen as a 
continuation of higher education collaboration during Soviet times, although in a new format. Members of this network share a similar educational past and are jointly searching for approaches to be incorporated into the global education space. The activities of these networks are limited to a few participating Kazakhstani institutions and are not influencing higher education policy on the national level. Another regional force that Kazakhstan became part of in 2014 is Asia-Europe Meeting (ASEM). ASEM promotes similar provisions as the Bologna Process, such as recognition of qualifications, involvement of business and industry in education, balanced academic mobility, and lifelong learning. The effect of this initiative have not been felt yet.

\section{Conclusion}

In this paper, we have looked at approaches for the internationalization of higher education in Kazakhstan based on policy documents, existing research, and Internet searches. In its current form, the internationalization of higher education in Kazakhstan has a dominant government influence, which includes initiation of various programs to reform and improve the quality of higher education. Higher education reform and quality improvement appear to be an important dimension of internationalization in Kazakhstan, which is not the same for the US or Western Europe, where internationalization does not imply a systemic reform of higher education or quality improvements.

Among other initiatives, joining the Bologna process is the main force that brings an international, predominantly European dimension to the Kazakhstani higher education system. Bologna compliance reforms, such as adopting ECTS created the ground for other internationalization activities, such as student mobility and joint degree programs.

Outbound student mobility is another important aspect of internationalization - Bolashak scholarship program, government mobility program combined with other grant opportunities and self-funding put Kazakhstan among the top-sending countries in the world. However, in the circumstances of shrinking student number in Kazakhstan it is considered as threat by local universities. There is other governmental support for internationalization like grants for faculty mobility, educational development programs that include international components, and the creation of a Western-style, Englishlanguage flagship university among others.

Thus, the internationalization higher education in Kazakhstan may be characterized as a top down approach that emphasizes internationalization "activities" with little focus on international / global competences, as a comprehensive approach to internationalization would (De Wit, 2009). 
Despite the influence of the Bologna process and the EHEA, the Soviet legacy can still be seen in the internationalization of higher education in Kazakhstan. Internationalization was happening even before independence from the Soviet Union, both within the Soviet Union and between Soviet-friendly countries. This legacy has extended to today, both in outbound and inbound student mobility. Several reasons may explain the ongoing prominence of Soviet ties, including the emergence of regional university networks and the ethnic composition of neighboring countries, as well as the asymmetric costs of study abroad for outbound and incoming international students.

\section{Acknowledgements}

We would like to acknowledge useful comments and help from our colleague Dr. Aisi Li. We are also grateful to Dr. Laura W. Perna and Kata Orosz, the editors of this special issue, for their helpful comments and suggestions.

\section{References}

Agarwal, V. B., and Winkler, D.R. (1985). "Foreign Demand for United States Higher Education: A Study of Developing Countries in the Eastern Hemisphere." Economic Development and Cultural Change 33(3): 623-644.

Ashirbekov, A., Jumakulov, Z., \& Lisnyak, S. (2013). Identifying the factors influencing the participation of Kazakhstani students in international scholarship programs. KAZNU Bulletin, 3(40), 36-45.

Biraimah, K., \& Jotia, L. (2013). The longitudinal effects of study abroad programs on teachers' content knowledge and perspectives. Journal of Studies in International Education, 17(4), 433-454.

Center for Bologna Process and Academic Mobility (2012). Strategy of CBPAM until 2020. Retrieved from http://naric-kazakhstan.kz/ru/o-tsentre/strategiya

Center for International Programs (2015). History of the program. Retrieved from http://www.bolashak.gov.kz/en/o-stipendii/istoriya-razvitiya.html on 09.09.2015.

Communiqué of the Conference of European Ministers Responsible for Higher Education (2009). The Bologna Process 2020: The European Higher Education Area in the new decade. Leuven and Louvainla-Neuve, 28-29.04.2009.

Concept of academic mobility of students studying in universities of the Republic of Kazakhstan (2011). Approved at the meeting of the Ministry of Education and Science on 19.01.11.

De Wit, H. (2009). Internationalization of higher education in the United States of America and Europe. Charlotte, NJ: Information Age Publishing.

De Wit, H. (2011). Internationalization misconceptions. International Higher Education, 64, 6-7. 


\section{HERJ Hungarian Educational Research Journal Vol 6 (2016), No 1}

De Wit, H. (2015). Quality assurance and internationalization: Trends, challenges and opportunities. Presentation at the INQAAHE conference; Chicago, IL. Retrieved from http://inqaahe.org/admin/files/assets/subsites/1/documenten/1429530892_inqaahe-keynotedewit.pdf on 10.01.2016.

Dixon, J. \& Soltys, D. (2013). Implementing Bologna in Kazakhstan: A guide for universities. Almaty-Astana: Academpress.

Eurasian National University (n.d.). Привлечение зарубежных специалистов в вузы РК [Attracting experts from abroad to Kazakhstani universities]. Retrieved from http://www.enu.kz/ru/uchebnyiprocess/doktorantura/privlechenie-zarubezhnykh-spetsialistov.php on 2.18.2016.

Geoff Maslen (2014). Mass movement of the world's students. University World News. Retrieved from http://www.universityworldnews.com/article.php?story=20140129200018337 on 11.01 .2016

Government of the Republic of Kazakhstan (2012). Привлечение зарубежных специалистов в вузы РК [Decree on approval of the selection rules of outstanding university faculty and spending conditions], dated February 17, 2012, Np. 235. Retrieved from http://www.enu.kz/ru/uchebnyiprocess/doktorantura/privlechenie-zarubezhnykh-spetsialistov.php

Government of the Republic of Kazakhstan (2015). Правила отбора претендентов для присуждения международной стипендии «Болашак» [Selection rules for awarding Bolashak international scholarship program]. Retrieved from http://bolashak.gov.kz/ru/pretendentu/pravila.html

Hartley, M., Gopaul, B., Sagintayeva, A., \& Apergenova, R. (2015). Learning autonomy: Higher education reform in Kazakhstan. Higher Education, online first, 1-13. doi:10.1007/s10734-015-9953-z

Hudzik, J. K. (2011). Comprehensive internationalization: From concept to action. NAFSA e-Publications. Retrieved from http://www.nafsa.org/uploadedfiles/nafsa home/resource library assets/publications library/20 11 comprehen internationalization.pdf

Information-analytical center (2015). National report on education system of th Republic of Kazakhstan. Astana, Kazakstan: IAC. Retrieved from http://edu.gov.kz/ru/analytics/nacionalnyy-doklad-osostoyanii-i-razvitii-sistemy-obrazovaniya-respubliki-kazahstan on 06.06.2016.

Jones, R. (2011). Energy exporters and the International Energy Agency. In: Shaffer, B., Ziyadov, T. (Eds), Beyond the resource curse (pp. 283-295). Philadelphia, PA: University of Pennsylvania Press.

Knight, J. (2008). Higher education in turmoil: The changing world of internationalization. Rotterdam, the Netherlands: Sense Publishers.

Kuraev, A. (2014). Internationalization of Higher Education in Russia: Collapse or Perpetuation of the Soviet System? A Historical and Conceptual Stud. Retrieved from Boston College University Libraries. (http://hdl.handle.net/2345/3799).

Law on Education (2015) of the Republic of Kazakhstan, dated 13.11.15. № 398-V. Retrieved from http://online.zakon.kz/Document/?doc_id=30118747\#sub_id=610000 on 18.01.2016

Law on Status of Nazarbayev University Nazarbayev Intellectual Schools and Nazarbayev Fund (2011). Dated 19.01.2011, $\quad$ № 394-IV. $\quad$ Retrieved from http://www.edu.gov.kz/sites/default/files/zakon_2011_goda_no_394.pdf on 15.03.2015. 


\section{HERJ Hungarian Educational Research Journal Vol 6 (2016), No 1}

Ministry of Education and Science of the Republic of Kazakhstan (2010). State program of education development in the Republic of Kazakhstan for 2011-2020. Retrieved from www.akorda.kz/upload/SPED.doc on 12.09.2015.

Ministry of Education and Science of the Republic of Kazakhstan (2014). State programme on industrial development of Kazakhstan. Retrieved from http://strategy2050.kz/ru/page/gosprog3/ on 05.09.2015.

Ministry of National Economy of the Republic of Kazakhstan (2015a). Retrieved from http://stat.gov.kz/getImg?id=ESTAT094363 on 10.03.2015.

Ministry of National Economy of the Republic of Kazakhstan (2015b). Retrieved from http://stat.gov.kz/getImg?id=ESTAT094365 on 10.03.2015.

Ministry of National Economy of the Republic of Kazakhstan (2015c). Retrieved from http://stat.gov.kz/getImg?id=ESTAT101667 on 10.03.2015.

Ministry of National Economy of the Republic of Kazakhstan (2015d). Retrieved from http://stat.gov.kz/getImg?id=ESTAT093178 on 10.03.2015.

$\begin{array}{llll}\text { Nazarbayev } & \text { University } & \text { (2013). } & \text { Strategy. }\end{array}$ http://nu.edu.kz/cs/groups/public/documents/document/mdaw/mdmy/ edisp/apkecm.nu.edu. 03261.pdf on 18.02.2016.

Nazarbayev University Graduate School of Education (2014). Development of strategic directions for education reforms in Kazakhstan for 2015-2020: Diagnostic report. Astana: Indigo Print.

Nazarbayev University Graduate School of Education (2015). Professional development program for higher education leaders of Kazakhstan. (Unpublished training materials.)

Network of CIS Universities (2015). Welcome page. Retrieved from http://www.ido.rudn.ru/su_sng/ on 24.11.2015.

Official Site of the Prime Minister of the Republic of Kazakhstan (2014). В 2014 году на реализацию программы «Болашак» будет направлено 16,5 млрд тенге - Г.Ныгыметов [16.5 billion Tenge will be allocated to the implementation of the Bolashak program]. Retrieved from https://primeminister.kz/strategy2050/show/72/81/v-2014-godu-na-realizatsiju-programmy\%C2\%ABbolashak\%C2\%BB-budet-napravleno-165-mlrd-tenge-gnygymetov-/21-02-2014 on 15.01.2015.

Omirbayev, S. (2016). Priorities of higher education in Kazakhstan in the context of internationalization. Presentation at the "Mechanisms of internationalization of higher education: Academic mobility, joint educational programs and international cooperation" workshop; Astana, Kazakhstan (Unpublished PowerPoint presentation).

Orazgaliyeva, M. (2014). Kazakhstan's Official Development Assistance to focus on Central Asia, Afghanistan (2014). The Astana Times. Retrieved from http://astanatimes.com/2014/10/kazakhstans-officialdevelopment-assistance-focus-central-asia-afghanistan-says-fm/ on 25.12.2015.

Organisation for Economic Co-operation and Development (2007). Reviews of national policies for education: Higher education in Kazakhstan 2007. Washington, D.C. / Paris: The World Bank / OECD Publishing. 


\section{HERJ Hungarian Educational Research Journal Vol 6 (2016), No 1}

Perna, L. W., Orosz, K., \& Jumakulov, Z. (2015). Understanding the human capital benefits of a governmentfunded international scholarship program: An exploration of Kazakhstan's Bolashak program. International Journal of Educational Development, 40, 85-97.

Perna, L. W., Orosz, K., Gopaul, B., Jumakulov, Z., Ashirbekov, A. \& Kishkentayeva, M. (2014). Promoting Human Capital Development: A Typology of International Scholarship Programs in Higher Education. Educational Researcher. Vol. 43, 2, 63-73.

Perna, L. W., Orosz, K., Jumakulov, Z., Kishkentayeva, M., \& Ashirbekov, A. (2015). Understanding the programmatic and contextual forces that influence participation in a government-sponsored international student-mobility program. Higher Education, 69(2), 173-188.

Sagintayeva, A., \& Ashirbekov, A. (2014). University involvement in the internationalization process. Higher Education of Kazakhstan, 1, 65-67.

Sagintayeva, A., \& Jumakulov, Z. (2015). Kazakhstan's Bolashak Scholarship Program. International Higher Education, 79, 21-23.

Silova, I. \& Steiner-Khamsi, G. (2008). How NGOs React: Globalization and Education Reform in the Caucasus, Central Asia, and Mongolia. Bloomfield, CT: Kumarian Press, Inc.

Sparks, J., Ashirbekov, A., Li, A., Parmenter, L., Jumakulov, Z., \& Sagintayeva, A. (2015). Becoming Bologna capable: strategic cooperation and capacity building in international offices in Kazakhstani HEIs. In: Bologna process researchers' conference: Future of higher education. Papers (pp. 109-126). Bucharest: Executive Agency for Higher Education, Research, Development and Innovation Funding (UEFISCDI).

SPFIID (2010). State program of forced industrial-innovative development 2010-2014, approved by the Order of the President of the Republic of Kazakhstan, 19.03.2010, No. 958.

SPIID (2014). State program on industrial development of Kazakhstan 2015-2019, approved by the Order of the President of the Republic of Kazakhstan, 01.08.2014, No. 874.

State Educational Standard of Republic of Kazakhstan (2011). Doctoral studies: Main Provisions ГОСО PK 5.04.034-2011, Article 8.18. Approved by the Order of the Minister of Education and Science on 06.12.2011.

State program for education and science development Action plan (SPESD) (2016). Retrieved from http://edu.gov.kz/ru/documents/proekt-plana-meropriyatiy-po-realizacii-gosudarstvennoy-programmyrazvitiya-obrazovaniya-i on 02.05.2016.

Stohl, M. (2007). We have met the enemy and he is us: The role of the faculty in the internationalization of higher education in the coming decade. Journal of Studies in International Education, 11(3-4), 359372.

Strategy Kazakhstan 2050 (2012). New political course of the established state. Retrieved from https://strategy2050.kz/en/multilanguage/ on 29.08.2015.

Tomusk, V. (2011). The geography and geometry of the Bologna process: Central Asian higher education in the new global periphery. In: Silova, I. (Ed.), Globalization on the margins: Education and postsocialist transformations in Central Asia (pp. 41-60). Charlotte, NJ: Information Age Publishing.

UNESCO (n.d.) Global flow of tertiary-level students. Retrieved from http://www.uis.unesco.org/Education/Pages/international-student-flow-viz.aspx on 2.18.2016. 
HERJ Hungarian Educational Research Journal Vol 6 (2016), No 1

University of Shanghai Cooperation Organization (n.d.). Цели и задачи [Goals and objectives]. Retrieved from http://uni-sco.com/stat/2/stat_2.html on 11.12.2015.

Woodword, D. (2011). Collaboration between Kazakhstan and the United Kingdom in higher education Inspire project. Almaty: Luxe Media Group.

Workshop on Mechanisms of Internationalization of Higher Education (2016). Recommendations to the Department of Higher Education of the Ministry of Education and Sciences of the Republic of Kazakhstan. Astana, 2.11-13.2016. 